\title{
Growth comparison between wild type and slick-haired Puerto Rican Holstein heifers ${ }^{1,2}$
}

\author{
Héctor L. Sánchez-Rodríguez ${ }^{3}$
}

J. Agric. Univ. P.R. 103(1):49-58 (2019)

\begin{abstract}
The present study compared the monthly body weight (BW) of 14 wild type (WT) and 11 slick-haired (SLICK) Puerto Rican Holstein heifers from four to $\mathbf{3 4}$ months of age at the Agricultural Experiment Station in Lajas, Puerto Rico. Data were analyzed by the GLIMMIX, GLM and REG Procedures in SAS. Hair coat type and age interacted to affect BW $(P=0.0005)$. However, no differences in BW were observed between WT and SLICK heifers (overall mean BW of $279.33 \pm 5.78$ and $275.06 \pm 6.91 \mathrm{~kg}$, respectively; $\mathrm{P}=0.3182$ ). From four to 34 months, BW increased in both the WT $(93.52 \pm 11.42$ to $446.35 \pm 28.27$ $\mathrm{kg} ; \mathrm{P}<0.0001)$ and the SLICK heifers $(85.69 \pm 9.97$ to $381.37 \pm 35.81 \mathrm{~kg}$; $\mathrm{P}<0.0001$ ). The interaction observed between hair coat type and age could be the result of different growth trends, as WT heifers presented a linear curve ( $B W=12.28$ age $\left.+54.41 ; R^{2}=0.88 ; P<0.0001\right)$; while their SLICK counterparts showed a quadratic regression $\left(B W=-0.32 a^{2} e^{2}+22.75\right.$ age $+6.24 ; R^{2}=0.74$; $P<0.0001)$ between $B W$ and age. These results suggest that SLICK heifers may reach maturity at an earlier age and with less BW. Future studies should evaluate if such differences affect the efficiency and productivity of these animals at maturity.
\end{abstract}

Key words: slick-hair, Holstein heifers, growth

\section{RESUMEN}

Comparación del crecimiento de novillas Holstein puertorriqueñas de pelaje normal y de pelo corto

El presente estudio comparó los pesos corporales (PC) mensuales de 14 novillas Holstein puertorriqueñas de pelaje largo normal (REGULARES) con los de 11 novillas similares, pero de pelo corto (PELONAS), entre los cuatro y $\mathbf{3 4}$ meses de edad. Las novillas evaluadas pertenecen al hato de la Estación Experimental Agrícola en Lajas, Puerto Rico. Los datos colectados fueron analizados mediante los procedimientos GLIMMIX, GLM y REG en SAS. El tipo de pelo y la edad interactuaron para afectar el $P C(P=0.0005)$. Sin embargo, no se observaron diferencias en PC entre las novillas REGULARES y las PELONAS (promedios generales de PC de 279.33 \pm 5.78 y $275.06 \pm 6.91 \mathrm{~kg}$, respectivamente; $P=0.3182$ ). Desde los cuatro hasta los 34 meses de edad, el PC aumentó tanto en las novillas REGULARES (93.52 \pm 11.42 a $446.35 \pm 28.27$

${ }^{1}$ Manuscript submitted to Editorial Board 21 September 2018.

${ }^{2}$ The author thanks agronomist Ricardo Montañez for the field data collection and Jessica Muñiz for typing the data into a computer software program.

${ }^{3}$ Associate Professor, Animal Science Department, University of Puerto Rico at Mayagüez. 
kg; $\mathrm{P}<0.0001)$, como en las PELONAS $(85.69 \pm 9.97$ a $381.37 \pm 35.81 \mathrm{~kg}$; $P<0.0001)$. La interacción observada entre el tipo de pelo y la edad puede ser el resultado de patrones de crecimiento diferentes, donde las novillas REGULARES presentaron una curva lineal $\left(P C=12.28\right.$ edad $+54.41 ; R^{2}=0.88$; $\mathrm{P}<0.0001)$; mientras que las PELONAS mostraron una relación cuadrática $\left(P C=-0.32\right.$ edad $^{2}+22.75$ edad $\left.+6.24 ; R^{2}=0.74 ; P<0.0001\right)$ entre $P C$ y edad. Estos resultados sugieren que las novillas PELONAS podrían alcanzar su madurez a una edad más temprana y con un menor PC. Estudios futuros deben dirigirse a evaluar si dichas diferencias podrían afectar la eficiencia y productividad de estos animales al alcanzar la madurez.

Palabras clave: pelaje corto, novillas Holstein, crecimiento

\section{INTRODUCTION}

In Puerto Rico, a tropical island, the dairy industry almost exclusively uses temperate Bos taurus cattle. However, these animals are highly susceptible to heat stress when exposed to hot weather compared with tropically adapted cattle (Adeyemo et al., 1979; Rocha et al., 1998). Fortunately, besides the normal long-haired wild type (WT) Bos taurus cattle, in Puerto Rico there is also a slick-haired phenotype (SLICK), a trait of the most important dairy breeds on the island. In recent years, several publications have confirmed that these Puerto Rican SLICK cattle are highly adapted to tropical weather, reporting lower body temperatures (Sánchez et al., 2015) and respiratory rates (Castro et al., 2015), as well as higher milk production values (Contreras et al., 2016) and larger sweat glands (Contreras et al., 2017; MuñizCruz et al., 2018) in comparison with similar WT cattle. However, all these studies have focused exclusively on mature cows, and knowledge is limited on whether superior thermoregulatory capacity affects these animals during earlier stages of life.

Dairy cattle use their energy budget to satisfy a series of physiological needs including maintenance, growth, reproduction and lactation, the order of which changes with the age and physiological state of the animal (Coppock, 1985). Immediately after weaning, for instance, the heifer does not have the capacity to reproduce and produce milk. Therefore, during its early stages of life, maintenance and growth are priorities of energy use. However, energy is also required to dissipate body heat and maintain thermal homeostasis (West, 2003; Capper et al., 2009), which is exacerbated in tropical countries. Thus, having a better thermoregulatory capacity may allow for a better energy budget for growing by decreasing the energy requirements for thermoregulation during the calf heifer stages. Yet, to this author's knowledge, published studies on body weight (BW) gain in WT and SLICK Puerto Rican Holstein heifers are highly limited. Therefore, the present study aimed to characterize how BW changes with age in WT and SLICK Puerto Rican Holstein heifers. 
MATERIALS AND METHODS

Animals and sampling

The present study compared the growth pattern of WT $(n=14)$ and SLICK ( $\mathrm{n}=11$ ) Puerto Rican Holstein heifers from the Agricultural Experiment Station of the University of Puerto Rico at Lajas, Puerto Rico (Figure 1). Heifer hair coat types were first phenotypically chosen and then genomically confirmed. Heifers included in the study were born
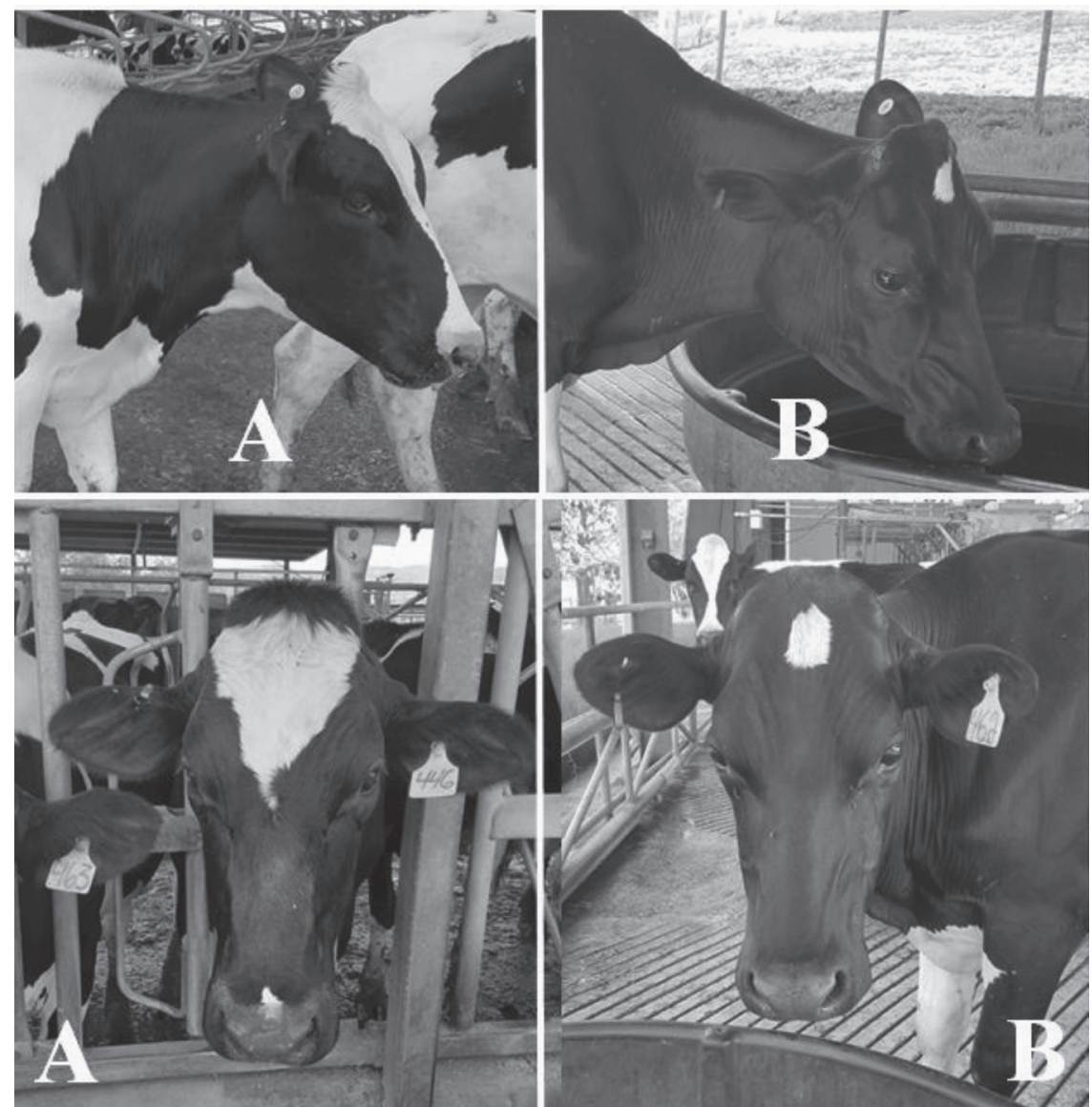

Figure 1. Examples of the Puerto Rican Holstein wild type (A) and slick-haired (B) heifers compared in the present study. In the slick heifers the hair coat is so short that wrinkles and veins can be noticed on the face and neck. Also, most of the slick-haired animals present a glossier hair coat and a smaller switch than the wild types. Abundant hair at the poll can be observed in the wild-type heifers, while the slick heifer's poll seems to have been clipped. 
between 21 October 2013 and 14 February 2015, weaned at 60 days of age and weighed monthly from four to 34 months of age on a livestock weighing system (Nasco, Fort Atkinson, WI) .

Statistical Analysis

Hair coat type groups were compared in terms of BW with Proc GLIMIMIX in SAS. Body weight was included in the model as the dependent variable. Hair coat type and age were considered fixed effects, while the heifer identification number was included as a random effect. Also, the relationship between BW and age was evaluated in both hair coat groups. The GLM and REG procedures were used to determine the best fit and the corresponding regression equation in each hair coat group, respectively. Significance was detected at $\mathrm{P}<0.05$. Data are presented as means \pm standard errors of the mean.

\section{RESULTS AND DISCUSSION}

Even though there was an interaction between hair coat type and age affecting $\mathrm{BW}(\mathrm{P}=0.0005)$, there were no differences in $\mathrm{BW}$ between the WT and the SLICK heifers (mean values over the 30-month evaluation period of $279.33 \pm 5.78$ and $275.06 \pm 6.91 \mathrm{~kg}$, respectively; $\mathrm{P}=0.3182$ ). As the heifers advanced in age from four to 34 months, BW increased in both the WT $(93.52 \pm 11.42$ to $446.35 \pm 28.27 \mathrm{~kg} ; \mathrm{P}<0.0001)$ and the SLICK heifers $(85.69 \pm 9.97$ to $381.37 \pm 35.81 \mathrm{~kg} ; \mathrm{P}<0.0001)$. The aforementioned hair coat type by age interaction may be the result of different growth trends observed in each hair coat group (Figures 2 and 3). In the WT heifers the growth curve was best explained by the linear regression: $\mathrm{BW}=12.28$ age $+54.41\left(\mathrm{R}^{2}=0.88 ; \mathrm{P}<0.0001\right)$; while in their SLICK counterparts, it was best described by the quadratic curve: BW $=-0.32$ age $^{2}+22.75$ age $+6.24\left(\mathrm{R}^{2}=0.74 ; \mathrm{P}<0.0001\right)$.

Normally, BW in dairy cattle increases at a fast linear rate during the juvenile stage, after which it gets progressively slower as the animal approaches maturity, when considerable change (related to growth) in the age-BW relationship is no longer observed (McDaniel and Legates, 1965; Berry et al., 2005). Thus, the fact that the evaluated WT heifers presented a constant linear growth trend throughout the entire evaluation period suggests that at 34 months of age, they are still in the juvenile growing segment of the curve. However, the quadratic growth curve observed in their SLICK counterparts shows that,

${ }^{4}$ Company or trade names in this publication are used only to provide specific information. Mention of a company or trade name does not constitute an endorsement by the Agricultural Experiment Station of the University of Puerto Rico, nor is this mention a statement of preference over other equipment or materials. 


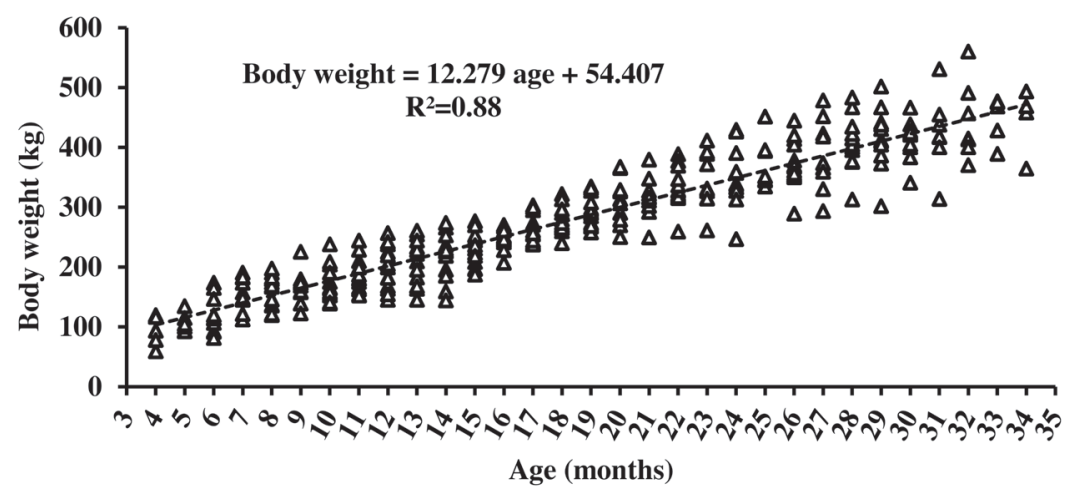

FIGURE 2. Body weight change by age in post-weaned wild type-haired Puerto Rican Holstein heifers. Growth curve is best described by a linear regression $(\mathrm{P}<0.0001)$.

at the same age, this group may be reaching mature body size. This finding suggests that the SLICK heifers could reach a smaller mature body size at an earlier age than their WT counterparts.

If such an assumption proves true, it would have multiple significant implications in a productive scenario. Reaching mature BW at an earlier age could represent a reduction in rearing costs per heifer. This is highly important because the heifer's rearing period represents considerable production costs (Gabler et al., 2000), which increase as the age of first parturition increases (Pirlo et al., 2000). In fact, Heinrichs (1993) stated that rearing heifers is the second highest cost in a dairy operation, only exceeded by the expenses related to feeding lactating

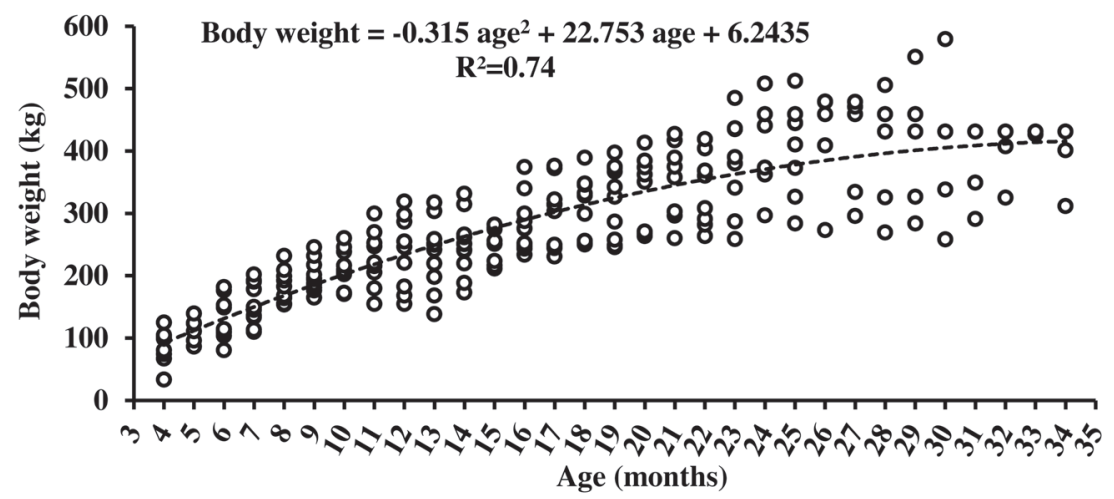

FIGURE 3. Body weight change by age in post-weaned slick-haired Puerto Rican Holstein heifers. Growth curve is best described by a quadratic regression $(\mathrm{P}<0.0001)$. 
cows. Obviously, the earlier the heifer matures, the earlier she may become pregnant, begin lactation and generate income, affecting positively the profitability of the operation. In fact, the sooner the SLICK heifers stop growing, the earlier they won't need to split their energy budget between growing and other important physiological processes, such as reproduction and milk production. Moreover, if there are differences in energy requirements during the growing stage, they could impact the age of the first pregnancy because as available energy increases, the age of onset of puberty is reduced (Johnson and Bernal, 1998), potentially allowing for an early pregnancy.

This author understands that since studies on growth efficiency, including SLICK heifers, are highly limited in the literature, a direct discussion is impossible in this manuscript. Still, the capacity of reaching maturity at a smaller body size could impact the future productivity of heifers as they become cows. Fortunately, there is plenty of scientific literature comparing mature WT and SLICK cows, which could be analyzed. The SLICK phenotype has been previously associated with greater productivity in Holstein cows from PR (Delgado et al., 2014; Contreras et al., 2016), in Senepol x Holstein crossbreds in Florida (Dikmen et al., 2014) and in Carora x Holstein crossbred cows in Venezuela (Olson et al., 2003). Such differences in milk yield may be related to the present results, as a smaller BW is usually associated with greater productive efficiency in dairy cows.

The concept of "dilution of maintenance effect" establishes that if two dairy cows with the same BW, but of different production levels, are compared, the one with the greater milk production will be more efficient (VandeHaar and St-Pierre, 2006; Capper et al., 2009; Bauman and Capper, 2010). This is so because energy requirements for maintenance, which are directly associated with BW (Demment and Van Soest, 1985; Veerkamp, 1998) do not change as milk production changes. Therefore, even though energy requirements for producing milk will increase as production rises, the total amount of energy the cow needs (maintenance + milk production) for every unit of milk produced will be reduced as production increases (total energy costs per unit of milk are diluted).

If SLICK heifers in fact mature at a smaller body size, some inferences about the "dilution of maintenance effect" concept could explain a greater productive efficiency later in the life of these animals. Generally, a smaller body size would represent smaller energy requirements for maintenance (Demment and Van Soest, 1985; Veerkamp, 1998). Therefore, even with similar productivity (and, subsequently, similar milk production-related energy costs), SLICK cows may have lower energy costs for maintenance, reducing total energy costs per unit of milk 
produced and probably permitting a greater fraction of the total energy budget to be used for milk synthesis. Moreover, as noted, SLICK cows achieve greater milk production than their WT counterparts. Therefore, SLICK cows could attain higher energy use efficiency by both a smaller maintenance requirement and the production of a greater volume of milk.

Since 1966, the University of Minnesota has selected Holstein cattle by body size resulting in two different herds, with either a small or large body size, that have been compared in several studies. Even though large framed cows are associated with a greater total volume of milk produced (Sieber et al., 1988), their smaller counterparts could be more profitable. The Minnesota small Holstein cows had a lower incidence of health problems (Mahoney et al., 1986), used their feed more efficiently (Yerex et al., 1988) and had longer productive lives (Hansen et al., 1999) than the large sized cows. Consequently, these studies suggest that selecting large Holstein cattle in the U.S.A. may be less profitable (Mahoney et al., 1986; Yerex et al., 1988; Hansen et al., 1999). Nonetheless, since 1977 the Holstein Association USA has considered a large body size as an important criterion for the ideal Holstein cow (Hansen, 2000); recently, however, the values promoting large animals in their indexes have been lowered (Geiger, 2017). Therefore, having a heifer that matures earlier and at a smaller body size could be advantageous in a production scenario.

Also, after basal maintenance requirements are met during early lactation, the major priority in terms of energy use (from feed and body reserves) is milk production (Coppock, 1985). As milk production increases during this lactation stage, the cow attempts to compensate by increasing its dry matter intake but, frequently, it is not enough, resulting in a period of negative energy balance (Coppock, 1985; Butler, 2000) where reproductive performance is limited (Collard et al., 2000). This problem has been exacerbated by the continuous genetic selection for greater milk volume per cow (Butler, 2000). Thus, smaller energy requirements for maintenance due to a smaller body size may permit a larger portion of the total energy budget to be available for milk synthesis, which would probably help alleviate the severity of this period.

Additionally, heat dissipation in cattle is directly associated with the surface area per unit of BW ratio (Hansen, 2004). The larger the ratio, the more efficiently the animal can dissipate heat to the environment (Norris and Kunz, 2012). This is crucial since, due to their large body masses, cattle produce a substantial quantity of metabolic heat (Silanikove, 2000). Additionally, when exposed to heat stress, the cattle's energy requirements for maintenance increase in an effort to dissipate heat (West, 2003; Capper et al., 2009). Fortunately, the smaller 
the $\mathrm{BW}$ of the animal, the larger the surface area to $\mathrm{BW}$ ratio (Berman, 2003) and the smaller the basal metabolic heat production (Silanikove, 2000). Therefore, heifers that reach smaller mature body size may have lower energy requirements to regulate body temperature, and, subsequently, a better energy budget for reproduction and milk production. In this regard it has been reported that mature SLICK dairy cows exhibit lower daily body temperatures (Sánchez-Rodríguez et al., 2016) and that they graze under the sun during the hottest period of the day in PR, while similar WT cows rest under the shade, lying in the mud (Sánchez-Rodriquez, 2019), suggesting better thermoregulation of the first group.

\section{CONCLUSIONS}

From four to 34 months of age, WT heifers presented a linear growth trend, while their SLICK counterparts showed a quadratic pattern. Such differences in the growth curves suggest that the SLICK heifers may reach maturity earlier and with a smaller BW. Available literature suggests that such differences in growth trends may affect future productive performance. Thus, future studies should be directed at evaluating whether the observed growth-related differences could, in fact, affect the age at maturity and the mature BW or dimensions. Also, studies on whether a smaller body size could be advantageous in terms of productive efficiency should be undertaken.

\section{LITERATURE CITED}

Adeyemo, O., E. Heath, B.K. Adadevoh, J. Steinbach and E.A. Olaloku, 1979. Some physiological and behavioural responses in Bos indicus and Bos taurus heifers acclimatized to the hot humid seasonal equatorial climate Int. J. Biometeorol. 23: 231-241. (Abstr.)

Bauman, D. and J. Capper, 2010. Efficiency of dairy production and its carbon footprint. Proc. Florida Ruminant Nutr. Conf., Gainesville, FL. pp 114-125.

Berman, A., 2003. Effects of body surface area estimates on predicted energy requirements and heat stress. J. Dairy Sci. 86: 3605-3610.

Berry, D.P., B. Horan and P.G. Dillon, 2005. Comparison of growth curves of three strains of female dairy cattle. Anim. Sci. 80: 151-160.

Butler, W.R., 2000. Nutritional interactions with reproductive performance in dairy cattle. Anim. Reprod. Sci. 60: 449-457.

Capper, J., R. Cady and D. Bauman, 2009. The environmental impact of dairy production: 1944 compared with 2007. J. Anim. Sci. 87: 2160-2167.

Castro, A., G. Muñiz, J. Curbelo, M. Pagán, A. Mesonero, A. de Jesús, N. Lluch and H. Sánchez, 2015. Effect of the environmental conditions over the vaginal temperature and respiration rate on wild type and slick-haired Puerto Rican Jersey cows. Joint Annual Meeting ADSA-ASAS 2015. July 12-16. Orlando, Florida.

Collard, B., P. Boettcher, J. Dekkers, D. Petitclerc and L. Schaeffer, 2000. Relationships between energy balance and health traits of dairy cattle in early lactation. J. Dairy Sci. 83: 2683-2690. 
Contreras-Correa, Z., G. Muñiz-Colón, M. Pagán-Morales, A. Mesonero-Morales, J. Curbelo-Rodríguez, and H.L. Sánchez-Rodríguez, 2016. Hematocrit, milk yield, and production related parameters comparisons between slick and wild type-haired Puerto Rican Holstein cows. Joint Annual Meeting, ASAS-ADSA-CSAS-WSASAS. July 19-23. Salt Lake City, Utah.

Contreras-Correa, Z., N. Peña-Alvarado, W. Torres-Ruiz, J. Almodóvar-Rivera, K. Domenech-Pérez, C. Youngblood, M. Pagán-Morales, A. Mesonero-Morales, J. Curbelo-Rodríguez, P. Randel-Follin, G. Muñiz-Colón, V. Colón-González, Á. JiménezArroyo, G. Jiménez-Arroyo and H. Sánchez-Rodríguez, 2017. Slick-haired Puerto Rican Holstein cows have larger sweat glands than their wild type-haired counterparts. ADSA 2017. June 25-28. Pittsburgh, Pennsylvania.

Coppock, C., 1985. Energy nutrition and metabolism of the lactating dairy cow. J. Dairy Sci. 68: 3403-3410.

Delgado, R., G. Colón, Z. Crespo, V. Colón, P. Cordero, G. Vargas, E. Lozada, E. Arcelay, C. Cabrera, E. Riquelme, G. Muñiz, A. de Jesus, N. Lluch and H. Sánchez, 2014. Asociación entre raza, tipo de pelo y producción de leche en vacas lecheras en Puerto Rico. Reunión Científica de la Sociedad para las Ciencias Agrícolas. Rincón of the Seas. Rincón, PR.

Demment M.W. and P.J. Van Soest, 1985. A nutritional explanation for body-size patterns of ruminant and nonruminant herbivores. Am. Nat. 125: 641-672.

Dikmen, S., F.A. Khan, H.J. Huson, T.S. Sonstegard, J.I. Moss, G.E. Dahl and P.J. Hansen, 2014. The SLICK hair locus derived from Senepol cattle confers thermotolerance to intensively managed lactating Holstein cows. J. Dairy Sci. 97(9): 5508-5520.

Gabler, M.T., P.R. Tozer and A.J. Heinrichs. 2000. Development of a cost analysis spreadsheet for calculating the costs to raise a replacement dairy heifer. J. Dairy Sci. 83(5): 1104-1109.

Geiger, C., 2017. Holstein moves reduce stature's impact. Hoard's Dairyman Intel. July $10,2017$.

Hansen, P., 2004. Physiological and cellular adaptations of zebu cattle to thermal stress. Anim. Reprod. Sci. 83: 349-360.

Hansen, L., 2000. Consequences of selection for milk yield from a geneticist's viewpoint. J. Dairy Sci. 83: 1145-1150.

Hansen, L., J. Cole, G. Marx and A. Seykora, 1999. Productive life and reasons for disposal of Holstein cows selected for large versus small body size. J. Dairy Sci. 82: 795-801.

Heinrichs, A.J., 1993. Raising dairy replacements to meet the needs of the 21st century. J. Dairy Sci. 76: 3179-3187.

Johnson, T. and G. Bernal, 1998. Diet energy requirements of growing Holsteins. J. Dairy Sci. 81: 840-845.

Mahoney, C., L. Hansen, C. Young, G. Marx and J. Reneau, 1986. Health care of Holsteins selected for large or small body size. J. Dairy Sci. 69: 3131-3139.

McDaniel, D. and J.E. Legates, 1965. Associations between body weight predicted from heart girth and production. J. Dairy Sci. 48: 947-956.

Muñiz-Cruz, J., N. Peña-Alvarado, W. Torres-Ruiz, J. Almodóvar-Rivera, K. DomenechPérez, Z. Contreras-Correa, G. Muñiz-Colón, A. Cortés-Arocho, J. Santiago-Rodríguez, S. Ruiz-Ríos, G. Soriano-Varela, N. Cortés-Viruet, A. Jiménez-Arroyo, G. Jiménez-Arroyo and H. Sánchez-Rodríguez, 2018. Sweat gland cross-sectional cut areas comparisons between slick and wild type-haired Holstein and Senepol cows in Puerto Rico. ADSA 2018. June 24-27. Knoxville, Tennessee.

Norris, A. and T. Kunz, 2012. Effects of solar radiation on animal thermoregulation. In: Babatunde, E.B. (ed), Solar Radiation. InTech, Rijeka, Croatia, pp195-220.

Olson, T.A., C. Lucena, C.C. Chase, Jr. and A.C. Hammond, 2003. Evidence of a major gene influencing hair length and heat tolerance in Bos taurus cattle. J. Anim. Sci. 81: 80-90.

Pirlo, G., F. Miglior and M. Speroni, 2000. Effect of age at first calving on production traits and on difference between milk yield returns and rearing costs in Italian Holsteins. J. Dairy Sci. 83: 603-608. 
Rocha, A., R.D. Randel, J.R. Broussard, J.M. Lim, R.M. Blair, J.D. Roussel, R.A. Godke and W. Hansel, 1998. High environmental temperature and humidity decrease oocyte quality in Bos taurus but not in Bos indicus cows. Theriogenology 49: 657-665. (Abstr.)

Sánchez, H., A. Castro, M. Pagán, J. Curbelo, A. Mesonero and G. Muñiz, 2015. Effects of the thermal humidity index on vaginal temperature of slick- and wild type-haired Puerto Rican Holstein cows. Joint Annual Meeting ADSA-ASAS 2015. July 12-16. Orlando, Florida.

Sánchez-Rodríguez, H.L., 2019. Revisión histórica y científica sobre el desarrollo de la ganadería de leche en Puerto Rico con énfasis en el ganado pelón. J. Agric. Univ. P. R. 103(1): 107-139.

Sánchez-Rodríguez, H., Z. Contreras-Correa, M. Pagán-Morales, J. Curbelo-Rodríguez, A. Mesonero-Morales, C. Cabrera-Cabrera and G. Muñiz-Colón, 2016. Associations between the environmental conditions and vaginal temperature in wild type and slick-haired Puerto Rican Holstein cows. Joint Annual Meeting, ASAS-ADSACSAS-WSASAS. July 19-23. Salt Lake City, Utah.

Sieber, M., A. Freeman and D. Kelley, 1988. Relationships between body measurements, body weight, and productivity in Holstein dairy cows. J. Dairy Sci. 71: 3437-3445.

Silanikove, N., 2000. Effects of heat stress on the welfare of extensively managed domestic ruminants. Livest. Prod. Sci. 67:1-18.

VandeHaar, M. and N. St-Pierre, 2006. Major advances in nutrition: relevance to the sustainability of the dairy industry. J. Dairy Sci. 89: 1280-1291.

Veerkamp, R., 1998. Selection for economic efficiency of dairy cattle using information on live weight and feed intake: A review. J. Dairy Sci. 81: 1109-1119.

West, J., 2003. Effects of heat-stress on production in dairy cattle. J. Dairy Sci. 86: 21312144.

Yerex, R., C. Young, J. Donher and G. Marx, 1988. Effects of selection for body size on feed efficiency and size of Holsteins. J. Dairy Sci. 71: 1355-1360. 